\title{
メンブレンフィルター免疫染色法を利用したスイカ種子からの スイカ果実污斑細菌病菌の検出と分離
}

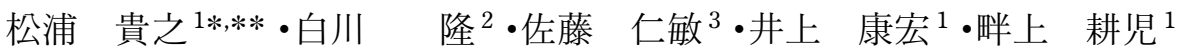

\begin{abstract}
MATSUURA, T. ${ }^{1 * * * *}$, SHIRAKAWA, T. ${ }^{2}$, SATO, M. ${ }^{3}$, INOUE, Y. ${ }^{1}$ and AZEGAMI, K. ${ }^{1}$ (2008). Detection and isolation of Acidovorax avenae subsp. citrulli from watermelon seeds using membrane filtration immunostaining. Jpn. J. Phytopathol. 74: 153-156.

We developed a new method to detect Acidovorax avenae subsp. citrulli in watermelon seeds, by modifying the membrane filter immunostaining method, which was developed to detect Burkholderia glumae in rice seeds. The detection threshold of this new method for A. avenae subsp. citrulli was several cfu per $100 \mathrm{ml}$ phosphate buffer using 1000 commercial watermelon seeds. Living cells of A. avenae subsp. citrulli could be obtained by stamping the membrane on selective medium plate before immunostaining.
\end{abstract}

(Received June 11, 2007; Accepted November 12, 2007)

Key words: Acidovorax avenae subsp. citrulli, bacterial fruit blotch, immunostaining, membrane filter, watermelon seeds, detection

スイカ果実污斑細菌病は, 1998 年に山形県のスイカに括い て国内で初めて発生が確認された（白川ら，2000）後, 鳥取 県 (佐古・船原, 2002), 長野県 (小木曾ら, 2001), 徳島県, 熊本県で散発的に発生が確認されている. 本病はAcidovorax avenae subsp. citrulli（以下, Aac) により引き起こされ, 種子 伝染することが知られている（Rane and Latinl, 1992）。また， 本菌による果実污斑細菌病は, スイカ以外にもトウガン (小 木曽ら，2005）, メロン（冨田ら，2006; 堀田ら，2006）で発生 が確認されて扣り, これらの発生原因も種子伝染であると報 告されている(小木曾ら，2005; 上松ら，2006）。そのため, 本病の発生を防止するには健全種子の供給が重要と考兄ら れ, 污染種子の混入を高感度・高精度に検出する検査方法の 確立が重要となる。 また, PCR や免疫学的手法で検出された 污染種子を感染源として証明するためには, 少なくとも生き た細菌を分離する必要がある. 現在まで污染種子からの Aac の検出方法は, 実際に種子を播種して幼苗に現孔る病徵観察
と，それに続く病原細菌の分離からなる Seedling Grow-out (USDA-APHIS National Seed Health System, 2004) と, 種子を 浸漬した緩衝液から Immunomagnetic beads を用いた Immunomagnetic separation and polymerase chain reaction (IMSPCR）でAac を検出する方法が報告されている（Walcott and Gitaitis, 2000). 前者は発病苗から Aac を分離するため信頼性 が高いものと考光られているが, 種子の Aac 污染率と苗での 発病は同等とは限らない.さらに，大量で多ロットの種子に ついて検定するためには育苗管理に多大な労力がかかり，か つ育苗場所の確保が必要となる。一方, 後者は多数の種子 ロットを迅速に検定することは可能であるが, PCR による判 定であることから死細菌を陽性とする危険性がある.

高精度な種子伝染性細菌病菌の検出法として,メンブレン フィルターと選択培地を用いて定量的に検出する方法 (メン ブレンフィルター免疫染色法）が考案されて打り，本法は 5000 粒のイネ種子に 0.1\%程度の割合でイネもみ枯細菌病菌

\footnotetext{
${ }^{1}$ 独立行政法人農業・食品産業技術総合研究機構中央農業総合研究センター（テ 305-8666 茨城県つくば市観音台 3-1-1） National Agricultural Research Center, Kannondai, Tsukuba, Ibaraki 305-8666, Japan

2 独立行政法人農業・食品産業技術総合研究機構野菜茶業研究所（T 305-8666 茨城県つくば市観音台 3-1-1） National Institute of Vegetable and Tea Science, Kannondai, Tsukuba, Ibaraki 305-8666, Japan

3独立行政法人種苗管理センター（テ 305-0852 茨城県つくば市藤本 2-2） National Center for Seeds and Seedlings, Fujimoto, Tsukuba, Ibaraki 305-0852, Japan

* Corresponding author (E-mail: matsuyu1@affrc.go.jp)

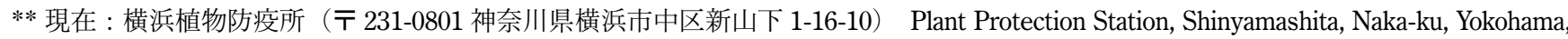
Kanagawa 231-0801, Japan
} 
Table 1. Bacterial isolates used in this study and reaction of dot immunobinding assay (DIBA) and PCR

\begin{tabular}{|c|c|c|c|c|c|}
\hline Species & Strain & Source & Locality & DIBA $^{\text {a) }}$ & $\mathrm{PCR}^{\mathrm{b})}$ \\
\hline \multirow[t]{7}{*}{ Acidovorax avenae subsp citrulli } & YPPS 319 & Watermelon seedling & Yamagata & + & + \\
\hline & YPPS 320 & Watermelon seedling & Yamagata & + & + \\
\hline & YPPS 349 & Watermelon seed & Yamagata & + & + \\
\hline & YPPS 355 & Watermelon seed & Yamagata & + & + \\
\hline & YPPS 371 & Watermelon seedling & Nagano & + & + \\
\hline & YPPS 430 & Watermelon fruit & Tottori & + & + \\
\hline & YPPS 452 & Watermelon fruit & Tokushima & + & + \\
\hline \multirow[t]{6}{*}{ Acidovorax avenae subsp avenae } & NARCB 200107 & Rice seedling & Kumamoto & \pm & - \\
\hline & NARCB 200304 & Rice seedling & Kumamoto & \pm & - \\
\hline & NARCB 200308 & Rice seedling & Kumamoto & \pm & - \\
\hline & AZ 92212 & Rice seedling & Kumamoto & \pm & - \\
\hline & AZ 92213 & Rice seedling & Kumamoto & \pm & - \\
\hline & AZ 92217 & Rice seedling & Kumamoto & + & - \\
\hline
\end{tabular}

Abbreviations: YPPS: Yokohama Plant Protection Station; NARCB: National Agricultural Research Center Bacterial Collection; AZ: isolated by K. Azegami in 1992

a) + : positive reaction, \pm : weakly positive reaction

b) + : a specific single fragment of 248 bp was amplified, $-:$ no amplification

Primers: Schaad et al. (2000)

污染種子が含まれる試料からも高精度に病原細菌を検出す ることができると報告されている(小原ら，2003）。そこで 本研究では, 1000 粒のスイカ種子からスイカ果実污斑細菌病 菌を高精度に検出, 分離するため, 既報の Aac 用選択培地 （以下，AacSM）（白川，2002）を用いたメンブレンフィル タ一免疫染色法の適用について検討した.

供試菌株 供試菌株として, 農林水産省横浜植物防疫所よ り分譲された Aac 7 菌株と本研究室に保存していたAcidovorax avenae subsp. avenae (以下, Aaa) 6 菌株を用いた (Table 1).

アルカリフォスファターゼコンジュゲート（IgG-AP）の 作製と反応特異性調査 アルカリフォスファターゼコン ジュゲート（IgG-AP）は，以下のように作製した。 まず，横 浜植物防疫所より分譲された抗 Aac（YPPS 319）血清よりア フィゲル MAPS-II キット（BIO-RAD）を用いて IgGを精製 した. IgG-APは，精製した IgGとアルカリフォスファター ゼ（Sigma, Type VII-S）を用いてグルタールアルデヒド 1 段 階法で作製した. 得られた IgG-APについて直接法によるDot Immuno Binding Assay（DIBA）（小宮ら，2002）での Aac の 検出限界と供試菌株の反応特異性を調査した。 その結果, IgG-AP 1600 倍に希釈した場合の検出限界は約 $10^{6} \mathrm{cfu} / \mathrm{ml}$ であり，供試した Aac の全菌株が反応した。 しかし, 対照で 供試した 6 菌株の Aaa にも弱い反応が認められ, 特に $\mathrm{AZ}$ 92217 菌株は, Aac とほぼ同等の強い反応を示した (Table 1). このことから, 免疫染色のみによる Aac の特異的検出は困難 と判断した.

種子浸漬液の検討 小原ら（2003）は，滅菌水にモミを浸 漬し超音波処理を行った後, メンブレンフィルターで集菌
し，イネもみ枯細菌病菌を效率的に回収している。また白川 （2002）は $0.01 \mathrm{M}$ のリン酸緩衝液（PB）を増菌のために用い ている. AacSM 上での培養実験から, Aac は $\mathrm{pH} 6.5$ ～ 8.5 で 生育可能であり，またスイカ種子を浸漬すると浸漬液の $\mathrm{pH}$ が酸性側に傾くことを考慮し，Aac の回収に用いる種子浸漬 液を 0.01 M PB（pH 8.0）とした.

メンブレンフィルター（MF）免疫染色法 $\mathrm{MF}$ 免疫染色 法は小原ら（2003）の方法に準じて行った。 まず，ガラス緎 維フィルター (47 mm 径; Glass Fiber Disks with Binder, Extra Thick ; Pall Corporation, P/N66078) と MF (孔径 $5.0 \mu \mathrm{m}, 47 \mathrm{~mm}$ 径，ポリカーボネート；MILLIPORE，TMTP04700）を重放 てセットしたリューザブルボトルトップフィルターシステ ム（Nalge Nunc International，500 ml）を用いて，試料液を 吸引ろ過して夾雑物を除去した。 そのろ液を，エタノールに 浸漬後滅菌水で置換することにより親水化した MF（孔径 $0.45 \mu \mathrm{m}, 47 \mathrm{~mm}$ 径, 疎水性ポリビニリデンフロライド; MILLIPORE，HVHP04700）をセットした同フィルターシス テムを用いて再度吸引ろ過し，MF 上に集菌した。集菌した $\mathrm{MF}$ を $\mathrm{AacSM}$ 平板培地にのせて, $37^{\circ} \mathrm{C} て ゙ 3$ 日間培養した.

培養後, MF の表面に Tween10 倍 TBS (0.02 M Tris, $0.15 \mathrm{M}$ $\mathrm{NaCl}, 0.5 \%$ Tween $20, \mathrm{pH} 7.5)$ を $3 \mathrm{ml}$ 滴下し，火炎隇菌した コンラージ棒で MF 表面に生育した細菌集落を剥離，除去し た，その MFを，Tween10 倍 TBSを $5 \mathrm{ml}$ 入れた径 $50 \mathrm{~mm} の$ シャーレに移し， 5 分間，室温で振とうした（80 rpm，以下 同じ)。その後，MFを 5 分間煮沸処理した後，ブロッキング 液 $(2 \%$ スキムミルク / Tween10 倍 TBS) に浸漬し，30 分 間，室温で振とうした。次に，Tween10 倍 TBS で 1600 倍に 
希釈した抗 Aac IgG-AP 液に MF を浸漬し, 1 時間室温で振と らすることにより，MF 上の細菌集落痕に対する血清反応を 行った. その後, 適量の Tween 10 倍 TBS で 5 分間ずつ 4 回 振とう洗浄した後, 基質液 (SIGMA, SIGMAFAST BCIP/NBT) で約 5 分間呈色反応を行った. 流水洗浄で呈色反応を停止さ せ，乃紙上に置き風乾した後，青紫色の呈色が観察された細 菌集落痕を陽性とした。

な抢，培養後の MFを免疫染色する前に，生菌の分離及び PCR による検出を可能とするため, MF 上の細菌集落を新し い $\mathrm{AacSM}$ 平板培地に転写し, $37^{\circ} \mathrm{C}$ で $2 \sim 3$ 日間培養した.

PCRによる確認 MF 免疫染色で陽性反応を示した細 菌集落痕の位置と対応するレプリカ AacSM 平板培地上の 集落について，Schaad ら（2000）の特異的プライマー (SEQID4 5'-TCGTCATTACTGAATTTCAACA-3', SEQID5 5'-CCTCCACCAACCAATACGCT-3') を用いたコロニーPCR を行った. PCRは, TAKARA Ex Taq (TAKARA) と GeneAmp PCR system 2400 (Perkin Elmer) を用いて行い, PCR 反応 液（TAKARA Ex Taq 0.5 U， dNTP $200 \mu \mathrm{M} ， 1 \times$ PCR buffer, 各プライマー $2.5 \mathrm{pmol} ）$ に $98^{\circ} \mathrm{C} て ゙ 5$ 分間処理した細菌懸濁 液 $5.0 \mu \mathrm{l}$ を鋳型として添加し, 総量を $20 \mu \mathrm{l}$ とした. 反応条 件は Walcott ら (2003) の方法に準じ, $95^{\circ} \mathrm{C} 5$ 分の後に, $95^{\circ} \mathrm{C}$ 30 秒, $53^{\circ} \mathrm{C} 30$ 秒, $72^{\circ} \mathrm{C} 30$ 秒を 35 サイクル繰り返し, 最後 に $72^{\circ} \mathrm{C} 5$ 分とした. PCR 産物を $2 \%$ のアガロースゲルで電気 泳動した後, 臭化エチジウムで染色した. 紫外線照射下で Aac に特異的な 248 bp の DNA 断片の増幅の有無を確認した.

以上の方法により供試した Aac 7 菌株及び Aaa 6 菌株につ いて PCR を行ったところ, Aac 7 菌株のみに特異的なバンド が検出された（Table 1).

\section{MF 免疫染色法の検出限界調査}

1）スイカ種子浸漬液に Aac を混入した場合 スイカ種子 (品種 : 縞王 $\mathrm{MK}$, 乾熱処理済久, 大和農園, 以下同じ) 約 1000 粒をガラス製秝じ口瓶（500 ml 容）中の $0.01 \mathrm{M} \mathrm{PB}$ （pH 8.0） $100 \mathrm{ml}$ に入れた後，最終濃度が，それ卆れ打よそ $1,10,10^{2} \mathrm{cfu} / 100 \mathrm{ml}$ になるように Aac（YPPS 319 株，以下こ
の株を試験に供試した）を添加した後，超音波洗浄機 (BRANSONIC 321, BRANSON) で 5 分間超音波処理を行って 試料液とした．その後 MF 免疫染色法でAac の検出及び分離 を試みた。また，添加した Aac の菌数は，希釈平板法により AacSM 平板培地上に形成された集落数から算出した. 3 回の 反復試験を行ったところ，希釈平板法で集落が検出されない 区に扔いても MF 上で陽性反応が観察された（Table 2)。ま た, $\mathrm{MF}$ 上の陽性集落痕に対応するレプリカ AacSM 平板培地 上の集落について PCR を行った結果，各処理区全てに扔い て Aac 飞特異的な DNA 断片の増幅が確認された。

2) スイカ種子にAac 人工污染種子を混合した場合 人工 污染種子は, Aac 懸濁液（抢よそ $10^{8} \mathrm{cfu} / \mathrm{ml}$ ) に 1 時間浸漬し た後，風乾することによって作製した．この人工污染種子の 平均保菌量は $40 \mathrm{cfu} /$ 粒, Seedling Grow-out による発病率は $36 \%$ であった．平均保菌量は人工污染種子 100 粒を $10 \mathrm{ml}$ の $0.01 \mathrm{M} \mathrm{PB}$ （pH 8.0）飞浸漬し，5 分間の超音波処理を行った 後, AacSM 平板培地に希釈平板培養することで算出した。 イカ種子 1000 粒当たり，そ机ぞれ $1 ， 5 ， 10$ 粒の人工污染種 子を混入し (1/1000 区，5/1000 区，10/1000 区)，前述と同様 に試料液を作製し，MF 免疫染色法でAac の検出と分離を試 みた．その結果， 1 粒の污染種子を混入した場合でも 5 反復 中 2 反復で陽性反応が観察された。しかし，5，10 粒の人工 污染種子を混入した区においても検出できない場合があっ た。また，MF免疫染色法で陽性となった集落痕に対応した レプリカ上の集落は，PCR により Aac 特異的な DNA 断片の 増幅が確認された（Table 3, Fig. 1).

以上の結果から, AacSM 平板培地を用いた MF 免疫染色法 を用いると，1000粒といった比較的大量のスイカ種子から高 感度にAacを検出できることが示された。 この手法は，選択 培地と抗血清を組み合わせることによって，浸漬液 $100 \mathrm{ml}$ 中 に数 cfu 以上の Aac が存在した場合には，確実に検出が可能 であった．しかし，人工污染種子を混合した場合は，検出で きる場合とできない場合があった．人工污染種子の平均保菌 量は $40 \mathrm{cfu} /$ 粒であったが，実際に1/1000 区に执いて，5回の

Table 2. Recovery threshold of Acidovorax avenae subsp. citrulli by membrane filter immunostaining (MFIS) method

\begin{tabular}{|c|c|c|c|}
\hline \multirow{2}{*}{$\begin{array}{l}\text { Putative colony number of } \\
\text { serialdilutions (per } 100 \mathrm{ml} \text { ) }\end{array}$} & \multicolumn{3}{|c|}{ Dot number ${ }^{\mathrm{a})}\left(\right.$ colony number) $\left.{ }^{\mathrm{b}}\right)$} \\
\hline & repetition 1 & repetition 2 & repetition 3 \\
\hline $10^{2}$ & $\mathrm{NC}^{\mathrm{c})}(79.0)$ & $\mathrm{NT}^{\mathrm{d})}$ & NT \\
\hline $10^{1}$ & $34(7.7)$ & $4(5.3)$ & $12(5.3)$ \\
\hline $10^{0}$ & $4(0)$ & $1(0)$ & $2(0)$ \\
\hline
\end{tabular}

\footnotetext{
a) Number of immunostained dots on membrane filter

b) Average number of colonies on three AacSM plates

c) Not countable

d) Not tested
} 
Table 3. Detection rate of Acidovorax avenae subsp. citrulli in watermelon seeds using membrane filter immunostaining (MFIS) after different levels of artificial infestation

\begin{tabular}{cc}
\hline Rate of Aac contaminated seed $(\%)$ & Detection rate \\
\hline $10 / 1000$ seeds $(1)$ & $2 / 3$ repetition \\
$5 / 1000$ seeds $(0.5)$ & $2 / 3$ repetition \\
$1 / 1000$ seeds $(0.1)$ & $2 / 5$ repetition \\
\hline
\end{tabular}

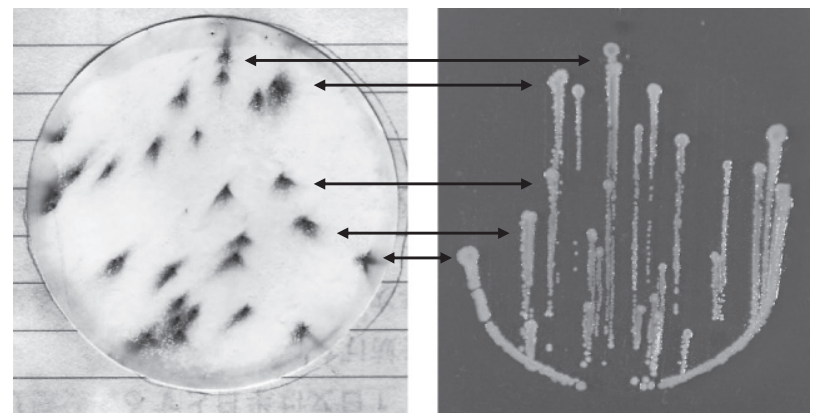

Fig. 1. Immunostained dots on membrane filter observed using membrane filter immunostaining (MFIS) method (left) and colonies of Acidovorax avenae subsp. citrulli (Aac) on replica AacSM plate (right). The arrows indicate the stains and corresponding colonies. Bacterial cells were trapped on a membrane filter after filtration of $100 \mathrm{ml}$ of $0.01 \mathrm{M}$ phosphate buffer ( $\mathrm{pH}$ 8.0) used to wash 1000 watermelon seeds. The seeds were contaminated with Aac cells at a rate of $0.1 \%$.

反復試験のらち MF 免疫染色法で確認された集落数は 0 個が 3 回，4個が 1 回，28 個が 1 回とかなりの差があった. 1)の 結果から，浸漬液中に $40 \mathrm{cfu}$ の Aac が存在していれば検出す ることが可能と考えられるが，必ずしもその様な結果になら なかったことから，混合した 1 粒の污染種子に扫ける Aacの 付着量が異なっていたことが原因の一つとして考えられる.

な抏, 一つの手法による特異的検出法では, 目的以外の細 菌も検出する可能性がある. そこで, 本手法では免疫染色に 加えて, 染色前に細菌を AacSM 平板培地に転写し, 得られ た集落に対して，特異的 PCR を行った，その結果，免疫染 色で疑陽性反応（Aacでないにもかかわらず免疫染色で呈色 反応を示した集落）を示した細菌を区別することが可能と なった。 また，このように生細菌を分離することで，病原性 の調査, 細菌学的性質調査を行らことができ, 分離細菌のよ り正確な同定が可能になる.

今回供試したスイカ種子は, 乾熱処理がされており, 常在 菌が少ないと考えられることから, 今後, 未消毒スイカ種子 を用い，この手法が適用可能か否かについて検証する必要が ある.さらに，今回作製した人工污染種子だけではなく，自
然污染種子を用いた場合にも，同様の感度で検出できるか否 かを調査する必要がある.

Rane と Latin（1992）は，自然污染種子，人工污染種子の 種皮及び肧の両方から Aac を分離しており，またWalcottら （2003）は花器感染が種子伝染につながると報告しているが, Aac の種子上の存在部位の詳細については未だ解明されてい ない、種子上の Aac 存在部位及び苗が発病にいたるまでの Aac の挙動の解明が，この病害の種子からの検出について重 要であり，今後詳細な調査をする必要がある.

本研究を行うにあたり, 試験用の種子を分譲してくださっ た（株）大和農園種苗販売部 浜田三紀夫氏にこの場を借り て厚く御礼申し上げます.

\section{引用 文 献}

堀田治邦・塚本貴敬・上松 寛・安岡眞二（2006）。日本で発生 した Acidovorax avenae subsp. citrulli によるメロン果実污斑 細菌病 (新称). 日植病報 72: 82 (講要).

小宮友紀子・白川 隆・我孫子和雄 (2002). Dot Immuno-Binding Assay 抢よびTissue Printing Immunoassayによるスイカ果実 污斑細菌病の血清学的診断法. 日植病報 68: 291-296.

小木曽秀紀・藤永真史・清水時哉（2001）。長野県に扣けるスイ 力果実污斑細菌病の発生. 関東東山病虫研報 48: 33-36.

小木曽秀紀・藤永真史・松崎良一・上松 寛 (2005). スイ力接 木苗に発生した台木トウガン種子に起因する果実污斑細菌 病. 日植病報 $71: 290$ (講要)。

小原達二・安達直人・畔上耕児 $(2003)$.メンブレンフィルター・ 免疫染色法によるイネ種子からのもみ枯細菌病菌の高感度 定量検出. 日植病報 69: 309-310 (講要).

Rane, K. K. and Latin, R. X. (1992). Bacterial fruit blotch of watermelon: association of the pathogen with seed. Plant Dis. 76: 509-512.

佐古 勇・船原みどり (2002)。栽培戒場で発生したスイカ果実 污斑細菌病の病徵の特徵と防除. 日植病報 68: 260 (講要).

Schaad, N. W., Song, W. Y. and Hatziloukas, E. (2000). PCR primers for detection of plant pathogenic species and subspecies of Acidovorax. US Patent 6146834.

白川 隆・菊池繁美・加藤智宏・我孫子和雄・ 川合 明 (2000). 日本に打けるスイカ果実污斑細菌病菌の発生. 日植病報 66: 223-231.

白川 隆 (2002)。 スイカ果実污斑細菌病の防除技術の開発. 農 林水産技術会議事務局 研究成果 401.

冨田恭範・小河原孝司・白川 隆・佐藤仁敏・鹿島哲朗・中西 宏 (2006). 茨城県に打けるスイカ果実污斑細菌病菌による メロン病害の発生. 日植病報 72: 312 (講要).

上松 寛・塚本貴敬・堀田治邦・佐藤成良 (2006)。 夕イ産又口 ン種子による Acidovorax avenae subsp. citrulli の伝搬. 日植 病報 72:46 (講要).

USDA-APHIS National Seed Health System (2004). Acidvorax avenae ssp. citrulli. In: Vegetable Crop Methods, http://www. nshs.iastate.edu/VEG. Crops. pdf

Walcott, R. R. and Gitaitis, R. D. (2000). Detection of Acidovorax avenae subsp. citrulli in watermelon seed using immunomagnetic separation and the polymerase chain reaction. Plant Dis. 84: 470-474.

Walcott, R. R., Gitaitis, R. D. and Castro, A. C. (2003). Role of blossoms in watermelon seed infestation by Acidovorax avenae subsp. citrulli. Phytopathology 93: 528-534. 